\title{
Comparison of different types of barley with variable crude fibre contents in growing-finishing pig diets
}

\author{
J.M. PEREZ *, O. LAVOREL **, M. LEUILLET ** \\ *I.N.R.A., Station de Recherches sur l'Elevage des Porcs, \\ Centre de Rennes-Saint-Gilles, F 35590 L'Hermitage \\ ** I.T.C.F., 8, avenue du Président-Wilson, F 75116 Paris
}

Two trials (A and B) were made with 98 and 96 fattening pigs, respectively, kept in individual pens to compare several types of barley with variable contents of crude fibre components under the same conditions of protein and energy supply.

A total of 7 batches of barley were compared in both trials : a naked barley, a spring barley, a two-row winter barley and two six-row winter barleys with a crude fibre content ranging from 1.9 to 6.6 p. 100 DM. Six batches of barley were compared in trial A (I.N.R.A.) and three batches of regular barley in trial B (I.T.C.F.). In each experiment the diets based on barley were compared to a control diet (maize-soybean meal). Several batches of raw materials were common to both trials.

In order to use the same energy restriction plan for all the animals we took into account the respective digestible energy values of the different kinds of barley measured in five of them during a previous digestibility study or estimated on the basis of their Weende crude fibre content according to the equation $Y=4072-110 \mathrm{X}$ established during the same study (Perez et al., 1980).

A single diet was offered in each treatment to females and castrated males and over the whole fattening period. All the diets exhibited the same lysine/energy ratio $(2.5 \mathrm{~g} / \mathrm{Mcal}$ ED).

The same trend were observed in both trials, but performances were slightly higher in trial B. For the same theoretical digestible energy supply were obtained very similar growth performance and carcass qualities with the different diets. The energy conversion ratios (Mcal ED/kg weight gain) were equivalent whatever the nature of the barley, showing that the energy value of the different barleys were properly adjusted.

\section{Animal fat enrichment of diets based on barley in piglets and bacon pigs}

\author{
J. CASTAING *, J. FEKETE **, F. GROSJEAN **, M. LEUILLET ** \\ * Association générale des Producteurs de Mä̈s, \\ 122 , boulevard Tourasse, $F 64000$ Pau \\ ** Institut technique des Céréales et des Fourrages, \\ 8, avenue du Président-Wilson, F 75116 Paris
}

Two experiments were made in young piglets of 8.4 to $23.3 \mathrm{~kg}$ and in bacon pigs of 23.8 to $104.2 \mathrm{~kg}$ to study the effect of an increase in the energy concentration of diets based on barley and soybean meal through the incorporation of animal fat.

In weaned piglets introduction of 3.5 points animal fat led to a marked improvement (4.6 p. 100) in the feed conversion ratio on the other hand, with 7 points fat the supplementary improvement of the ratio was too small (lower than 2 p. 100). In both cases growth was not modified.

In the bacon pig, introduction of 3 to 6 p. 100 animal fat resulted in our experimental conditions in a slight improvement of the growth rate. 